\title{
REGIONAL IMPACT OF THE GLOBAL ECONOMIC CRISIS on the Freq State Province in SoUth Africa: A COMPUTABLE General EpUILIBRIUM (CGE) ASSESSMENT
}

\author{
Helene Maisonnave* \\ University of Le Havre, France
}

\author{
Margaret Chitiga+ \\ University of Pretoria
}

Received: May 2015

\author{
Jugal Mahabir* \\ University of Johannesburg \\ Ramos Mabugu\$ \\ Financial and Fiscal Commission, \\ Stellenbosch University
}

Accepted: November 2015

\begin{abstract}
The decline in the world economy that followed the 2008-2009 global economic crisis had detrimental effects on most economies. Not enough attention has been paid to the process through which crisisrelated pressures affected regional economies and sub-national governments. A regional computable general equilibrium model was developed to analyse impacts of the crisis on the regional economy of the Free State province in South Africa. Key results included a general fall in prices in the province, a fall in demand in sectors that are more vulnerable to global conditions, falling wages and declining incomes for agents and provincial government
\end{abstract}

Keywords

Regional computable general equilibrium, South Africa, global economic crisis, economic impact, crisis response

*Dr H Maisonnave is an associate professor in the Department of Economics at the University of Le Havre, France.

\#Mr J Mahabir is a lecturer in the Department of Economics and Econometrics at the University of Johannesburg, South Africa and a Research Associate at the Public and Environmental Economics Research Centre at the University of Johannesburg. [jmahabir@uj.ac.za]

+Prof M Chitiga is the Director and Head of the School of Public Administration and Management at the University of Pretoria, South Africa.

\$Dr R Mabugu is the Research Director at the Financial and Fiscal Commission and a Research Associate at the University of Stellenbosch, South Africa. 


\section{INTRODUCTION}

The decline in the world economy that followed the 2008-2009 global economic crisis had detrimental effects on most industrial economies, some of which are still being felt today. After a lag, the impact was also felt by most developing countries, including South Africa, driven largely by a fall in international demand for commodity exports. In the face of the ensuing recession and depleting tax revenues, national government attempted to maintain the existing quantum of its social service delivery policies and infrastructure roll out using greater debt financed spending. This stimulatory fiscal arrangement, in unison with expansionary monetary policies, countered the negative impact of the recession on aggregate demand. Although policies are driven at the national level, South Africa has a complex intergovernmental system consisting of three interdependent and interrelated spheres that are integral in the provision of social programmes and service delivery. Most social services, such as education and health, are delivered by provinces while local government provide key basic services in the form of water, sanitation and electricity, amongst others.

Given this triple layered system of service delivery that exists, it becomes apparent that the impact of the global economic crisis and an assessment of the policies employed to counter a decline in national productivity and service provision cannot be analysed in isolation from the sub national economy and administration. Most assessments of the impact of the recession have tended to be at the aggregated national level.

This paper uses a static computable general equilibrium (CGE) model to analyse the impact of the economic crisis on the Free State regional economy, a provincial government in South Africa. CGE models are able to capture the external shocks that emanated from the global crisis and evaluate the impacts of such shocks on the different sectors of the economy and its agents. Analysing the impact of the global crisis on the Free State province offers a perspective, unique to that of the rest of the South African economy, given that the province is landlocked, is relatively poorer than other regions and has a larger rural economy. The Free State economy has also experienced a transitory shift from dependence on primary and secondary industries towards tertiary industries, placing it in a unique economic situation at the time of the global crisis.

The contribution of this paper is two-fold: (1) its sub national governmental and regional economic focus and (2) an intuitive and quantitative understanding of the transmission channels through which sub national economies are ultimately affected by global economic recessions. Furthermore, the ex-post comparison between the simulated model results and observed economic trends allows for conclusions regarding the robustness of the modelling framework in quantifying the impacts.

The rest of the paper is divided as follows: section 2 gives a brief description of the Free State province and an intuitive understanding of potential transmission channels of the global crisis. Section 3 offers a review of existing related literature. Section 4 gives a description of the data and the model used. Section 5 describes the scenarios and also presents results and analysis. Section 6 concludes the paper.

\section{THE FRE\& STATE PROVINCE}

The Free State province has a population of 2.7 million people, which is approximately $5.3 \%$ of the South African population according to the 2011 Census (Statistics South Africa, 2012). The 
province is centrally located, bordering 6 other South African provinces and the country of Lesotho. The Free State province has experienced a transitory shift from dependence on primary and secondary industries towards tertiary industries. The tertiary services sector now contributes more than half of the province's gross domestic product (GDP) whereas agriculture accounts for only $6 \%$.

Most of the commodities produced in the province are consumed within the region, which can suggest that external economic shocks would not impact as heavily on domestic demand. The sector that is most likely to be impacted on by an external shock would be mining, as mining is exclusively exported. Most mining exports from the Free State province consist of gold, which retained a relatively stable price during the recession.

The correlation between GDP growth in the Free State and South Africa was relatively strong in the years prior to the crisis. As shown in FIGURE 1, a decline in national GDP usually results in a similar declining trend in the province but the magnitude is more severe within the regional economy. This suggests that the structure of the Free State economy might be strongly related to the national economy. One can notice the downturn in the economy after a sustained period of growth in 2008 in both South Africa and the Free State. This was the first sign of the impact of the global crisis. It is important to also note that the Free State GDP growth rate has been lower than the national GDP growth rate, suggesting that other regions are growing at a faster pace.

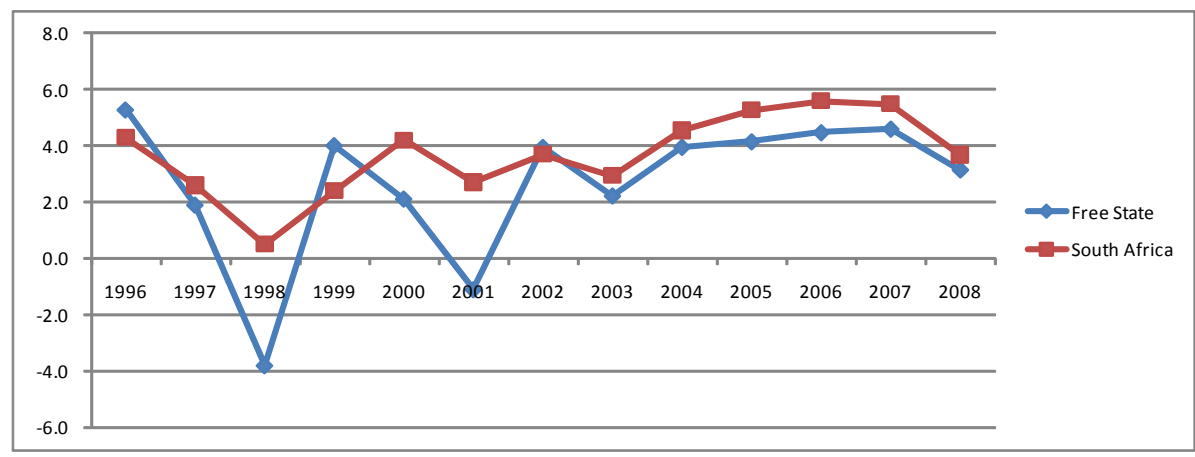

FIGURE 1: GDP growth in Free State and South Africa (\%) - Pre-crisis

Source: Statistics South Africa (2009)

The Free State provincial government is responsible for the provision of social services such as education, health, housing and social development. The most significant income source for the provincial government is transfers from national government. Transfers from households and corporations in the form of provincial taxes are minimal, comprising only $4 \%$ of total revenues.

Given the economic structure and characteristics of the Free State province just discussed, the impact of the global crisis on the dominating private sector is likely to be important in terms of indirect effects from the rest of South Africa. With regards to government, it can be expected that a recessionary climate would result in provincial revenues decreasing considerably and provincial government spending on social and welfare services would be affected negatively. As a consequence, the poor in the province that benefit the most from such expenditure would be affected negatively. Since provinces rely heavily on transfers from national government as their major source of revenue, national government can protect the financial situation of provinces 
and ensure that basic social services and grants are rolled-out in their existing quantum, albeit at the expense of rising budget deficits.

\section{LITERATURE REVIEW}

The response of various national economies to the economic downturn has been assessed extensively in the aftermath of the 2008 global financial crisis, including that of the South African economy (see for instance, Chitiga, Decaluwé, Mabugu, Maisonnave, Robichaud, Shepherd, van der Berg \& Von Fintel, 2012). Research has ranged from analysing the impact of the crisis on both developed and developing economies (see for instance Estrades and Llambí, 2013, for Uruguay).

There are relatively few regional studies that have tried to quantify the impact of the crisis on subnational economies, with none using quantitative methods such as CGE modelling. The following review of selected studies for different regions presents briefly their research approach and the results.

The Western Australian Local Government Association (2009) highlighted the importance of regional governments in the delivery of services, infrastructure provision and regional economic development. Their largely descriptive study highlighted two important considerations when assessing recessions on regional governments and economies resulting from the global financial crisis. Firstly, the extent of recessionary impacts is likely to be different across sub-national governments. This varying impact depends on the specific channels through which the recession impacts the national economy, in general, and the extent to which sub-national economies replicate such channels. Secondly, sub-national governments are likely to have a limited ability to curb recessionary impacts on regional economies.

Ter-Minassian and Fedelino, 2009, assessed the impacts of the global financial crisis on the finances of sub-national governments for Spain. Their assessment also reiterated the limited literature assessing the impacts of the financial crisis on sub-national governments, which they suggest is due to the limited abilities of sub-national governments to deal with a recession and the general lack of data at sub-national government level to assess regional economic responses. The study used mainly qualitative techniques to assess the impacts on sub-national finances and find both a direct impact (through a decline in local tax revenues) and indirect impact (through a decline in intergovernmental transfers driven by a decline in the revenues of central governments) on sub-national revenues. The authors found that, although central governments are responsible to counter a recession induced by the financial crisis through expansionary fiscal policies, 'a sizeable part of the stimulus spending, albeit decided and financed by central governments, had to be executed by sub-national governments' (Ter-minassian and Fedelino, 2009: 602). Thus, greater debt financed expenditure by the national government can protect the finances of sub-national governments by maintaining the existing quantum of transfers to provinces. However, the paper did emphasise that there was a decline in shared revenue sources in many countries (such as France and Brazil), which is an important source of revenue for many sub-national governments.

Ter-minassian and Fedelino, 2009, present different potential direct impacts of the financial crisis on the finances of sub-national government: (1) cyclical economic pressures result in declining revenues from own tax sources (2) consumers become unable to pay local taxes (3) there is a greater demand for social services and related expenditures due to the negative social impacts of the crisis (4) bailouts of financial and non-financial entities can be possible (5) the 
interest payments might increase if the sub-national government has debt financing expenditure and (6) returns to investments might decline if the sub-national government has investments. The extent of these direct impacts is influenced by several factors: the size of the decrease in regional production and employment, the mix between revenue sources, the nature of the expenditure powers and functions assigned to sub-national governments and their ability to borrow.

Bowo, 2009, undertaking a qualitative study on the impact of the crisis on Jakarta, conceded that a regional government has limited powers in curbing a general recession on its local economy. However, the author found minimal negative impacts on the economy of Jakarta as a result of the global financial crisis.

For South Africa, the analysis of the recession's impact is only available at national level. Chitiga et al., 2012, quantified the impact of the shock of the financial crisis using a dynamic microsimulation CGE analysis. They simulated two possible recessionary impacts on the South African economy that could result from the financial crisis. They identified three transmission mechanisms: a decrease in world prices, a massive drop in world demand, and a decrease in foreign direct investment.

This paper complements the existing studies by giving an intuitive and quantitative understanding of the transmission channels through which sub national economies are ultimately affected by global economic recessions using a static CGE model. It is the first study to quantify the impacts of the international crisis on a regional government and economy in the South African case. The development of the Free State province CGE model takes into account the interdependence of the different activities and agents in the province and the links between the different levels of government in the country. Thus, the model allows for the analysis of the global crisis on the specific economic structure of the Free State, while also isolating the impacts of the recession on individual agents and the regional government in the province.

\section{DATA AND MODEL}

CGE models represent whole economic systems: they describe the relationships between the different activities of the economy and the economic agents. Originally, CGE models were designed to analyse the impact of policy scenarios on economies at global and national levels. Recently, CGE models have become more often used in regional policy analysis (see for instance Partridge and Rickman, 2010; Haddad, Bonet, Hewings \& Perobelli, 2009; Decaluwe, Lemelin and Bahan, 2010).

The CGE model database consists of a Social Accounting Matrix (SAM). In this study the SAM was developed in 2006 by the Free State provincial government and the Development Bank of South Africa (Free State Provincial Treasury, 2006). The SAM has 44 activity accounts, divided into 2 agricultural services (commercial and subsistence), 2 mining services (gold and other mining), 8 public/government services (including provincial and local government), 13 private services (including business activity and other tertiary sector services) and 19 manufacturing sectors (including textiles, fruits and dairy products) (Please see Appendix 1 for a detailed list). There are 66 institutional accounts divided up into 48 households, 4 corporations, 12 government accounts and 2 non-resident accounts. The 4 race groups and 12 income deciles ranging from lowest to highest divide households in the SAM. The labour force is disaggregated by occupation (managers, professionals, technical professionals, clerks, services workers, skilled agricultural 
workers, craft workers, machine operators, elementary occupation workers and domestic workers) and population group (African, Coloured, Indian and White).

To evaluate the impacts of the world economic crisis on the Free State province, we use the Partnership for Economic Policy (PEP) model by Decaluwé, Lemelin, Maisonnave \& Robichaud, 2009 , changing several assumptions to better reflect the Free State provincial economy. There are two main differences to the PEP standard model that are introduced here. The first one comes from the disaggregation of government to national, provincial and local levels. Our model takes into account the different levels of government and the relationships between them. With this disaggregation, we will be able to capture the effects of the external shock, (the crisis), on the regional government.

The other difference with the PEP standard model comes from the disaggregation of the rest of the world. In our study, we model the region 'Free State' and its relations with the rest of South Africa (the other 8 provinces) and the rest of the world (e.g. Lesotho, China, Europe, etc.). Each partner receives income from their sales in the province (the Free State imports), as well as a share of provincial capital revenue and labour revenues. The latter represents workers that work in the province but live in other provinces or in a nearby country (Lesotho in this case). Income from capital goes to firms or individual entrepreneurs that own capital in the Free State province. Each trading partner buys commodities made in the Free State (the Free State exports) and pays wages and capital rents to the Free State, the latter of which represents the Free State workers and capital owners that operate outside the province.

The Free State can export to the other South African provinces or to the rest of the world. Note that some products, such as gold, are only exported to the rest of the world, while others are only exported to the rest of South Africa (e.g. water).

On the demand side, the Free State consumers can buy products made in their province, or import products from the rest of South Africa or the rest of the world. In addition, the SAM does not have margins or transport costs. As a result, a consumer in the Free State pays the same price for a product made in their province as elsewhere in South Africa. Modelling transport margins is beyond the scope of the present paper.

The nominal exchange rate is the numeraire of the model. As this is a static model, labour and capital supplies are fixed. The current account balance is also fixed. We assume that South Africa has constraints in borrowing from the rest of the world. Moreover, it is assumed that transfers between governments are fixed. In other words, a fall in national government's income will not be followed by a concomitant drop of its transfers to provinces for instance. This assumption is consistent with what was observed in South Africa. Indeed, during the course of 2008-09 and 2009-10, the South African government's fiscal position moved from a small surplus (of approximately $1.5 \%$ of GDP) into a substantial deficit (of approximately $6 \%$ of GDP), showing the counter-cyclical role of government spending and revenue decisions consistent with this closure.

\section{SCENARIO AND FINDINGS}

\subsection{Scenarios}

Based on the results of the South African national assessment by Chitiga et al., 2012, we assume that the transmission channels of the recession on the Free State regional economy are likely to be similar to those of South Africa in general. This assumption is supported by the analysis in 
FIGURE 1 where there is a strong correlation between the movement in the South African GDP and that of the regional gross domestic product (GDPR) of the Free State economy. Therefore, the province will be affected through a decrease in world prices (of imports and exports) and a drop in world demand for such products. There are thus two main mechanisms here operating simultaneously: a decrease in world demand and a decrease in the price exporters get when they export their products. Given the decrease of exports, producers will have to reallocate their production or to decrease their production (i.e. lay off workers).

Following Chitiga et al. (2012), we split the Free State economy into four different groups of activities, with each group defined by its degree of dependency/exposure to the global crisis. The groups are informed by observation of the crisis' impact on the South African sectors. The four groups are:

- Unaffected sectors (Group 1): It is assumed that these sectors will face neither a reduction in foreign demand nor a reduction in international prices (i.e. gold, food and beverage commodities).

- Weakly affected sectors (Group 2): These sectors are not heavily dependent on foreign trade and not closely related to other sectors (i.e. agriculture, clothing and wood). This group will suffer a decrease of $2 \%$ of its export and import prices.

- Mildly affected sectors (Group 3): Like the previous group, these sectors are not heavily dependent on foreign trade but are closely linked to other sectors. Such sectors will react to a reduction in consumption, investment expenditures or reduction in demand for intermediate goods (i.e. most transports products, trade and construction). This group will suffer a decrease of $3.5 \%$ of its export and import prices along with a decrease of $2 \%$ in world demand for exports.

- Strongly affected sectors (Group 4): These sectors are closely linked to international markets either on the export or the import side (i.e. fossil fuels, other mining, machinery and equipment). This group will suffer a decrease of $5 \%$ of its export and import prices, along to a decrease of $2 \%$ in world demand for exports.

\subsection{Findings}

\subsubsection{Impact on prices}

A drop in world demand and world prices leads to a decrease in prices producers get when they export, imported prices in local currency (as world import prices are going down) and therefore in local prices as shown in TABLE 1. The first price in TABLE 1 (price of exports) is a weighted mean between the export prices (exports from the rest of the world and exports from South Africa). Recall that the average export price is the price a producer gets when exporting, depending on the different markets for exports. Here, unlike in a national model, the producer has two exports markets, namely, the rest of South Africa and the rest of the world. On average, the exporter gets a weighted mean (by the quantities of exports). World prices that are exogenous in the model are shocked only for affected commodities. At the same time, export demand is shocked. This has a downward pressure to the Free on Board (FOB) prices, and therefore to the average export price the producer gets, ceteris paribus.

The strongly affected sector prices decreased by $3.32 \%$ following an external shock of $5 \%$ combined with a decrease in demand for Free State exports of $2 \%$. This result is weighted by the 
quantities. If most of the exports are directed to the rest of South Africa (and that is mainly the case, except for gold products), the strong decrease in world price does not have a massive impact on the average export price the producer gets. In general, export prices from the rest of the world are sharply dropping, whereas export prices from the rest of South Africa are in fact equal to local prices. The same phenomenon is observed for import prices.

TABLE 1: Impact on prices (in \%)

\begin{tabular}{lccc}
\hline \multicolumn{1}{c}{ Sectors } & Exports & Import & Local \\
\hline Non affected & -0.74 & -0.8 & -1.01 \\
Weakly affected & -1.17 & -1.46 & -1.07 \\
Mildly affected & -1.94 & -2.45 & -1.4 \\
Strongly affected & -3.32 & -3.2 & -2.6 \\
\hline
\end{tabular}

Source: Authors' calculations

\subsubsection{Impact on exports, imports and local demand}

As expected, exports decrease significantly for products belonging to the strongly affected group (TABLE 2). Non-affected sectors benefit from this situation, notably the gold sector. Indeed, local prices are decreasing more than export prices for non-affected sectors. Thus, there is a greater incentive for a producer to sell their production abroad. In the same way, for the other sector groups, it can be observed that imports drop less than local sales. This comes from the fact that import prices drop more than local prices (see TABLE 1). Thus, a consumer will prefer buying an imported good that will now be cheaper.

TABLE 2: Impact on exports, imports and local sales (in \%)

\begin{tabular}{lccc}
\hline \multicolumn{1}{c}{ Sectors } & Exports & Import & Local \\
\hline Non affected & 1.37 & 0.6 & 0.39 \\
Weakly affected & -0.04 & 0.58 & 0.28 \\
Mildly affected & -0.9 & -1.33 & -0.45 \\
Strongly affected & -1.76 & -2.99 & -3.60 \\
\hline
\end{tabular}

Source: Authors' calculations

\subsubsection{Impact on production}

The decrease in the total demand for goods will have consequences for sectoral production. One would actually expect sectoral production to decrease, and that the decrease should be stronger for sectors strongly dependent on exports. On the other hand, sectors that are not directly affected by the crisis might be affected by a reduction of other sectors' demand, in terms of intermediate consumption for instance. This is the case for all transport and trade sectors. However, the gold sector sees its production increasing by $1.15 \%$. It is important to remember that the gold industry does not face a decrease in its world prices or world export demand following a global crisis. Generally, when a crisis occurs, the gold sector is one of the few sectors that are not 
affected because investors consider it a safe investment option (so-called 'safe haven'). Production in the electricity sector is indirectly benefiting from the increase in production in the gold sector $(+0.54 \%)$, as electricity constitutes an important intermediate good for the gold sector.

\subsubsection{Impact on labour demand and wages}

The decrease in the production of most sectors has consequences in terms of employment and wages, as firms are likely to adjust their costs. It is intuitive that firms will decrease their labour demand and will simultaneously decrease their demand for intermediate consumption given the reduction in the level of activity. Labour demand is increasing for sectors that are not affected by the drop in world prices and world demand (gold, electricity and public sector) while the other sectors have to lay off workers.

Wage rates for all but one category of workers decline. Modelling wage rigidity is beyond the scope of this paper. Therefore, wages are adjusting in this model. With rigid wages, the impacts would be stronger on unemployment. The only category that sees its wage increasing is professional African. The reason is that national government, water and gold sectors are relatively intensive users of this type of labour.

\subsubsection{Impact on institutions}

Given the decrease in wage rates, households' income in nominal terms falls. The decrease in income leads to a decrease in households' consumption as well as their savings. However, it can be pointed out that the poorest households are not the ones who see their income decreasing the most due to the South African government transfers to such households (mainly social grants) remaining fixed.

Clearly, a fall in household savings will have negative implications for future investment. The most concerning outcome however, is the massive drop in firms' savings. As firms' savings is the main contributor to total investment, this development threatens future growth prospects for the province. As the model used for this study is static, a discussion of future projections is reserved for further empirical work in the future.

\subsubsection{Impact on governments and investment}

National government's income depends on agents' taxes (that are decreasing) and taxes on products (that are also decreasing due to the drop in sales). Therefore, national government income is decreasing $(-1.6 \%)$. In line with the closure, it is assumed that the transfers national government makes to other agents are fixed. This leads to a sharp decrease in government savings $(-13.10 \%)$ (Government's expenditure is fixed as well as transfers). For provincial government, the main source of income is national government's transfers. They also receive a share of capital income (that is decreasing). Overall, provincial government's income decreases by $0.03 \%$. Note that the provincial government spends all its income (on provincial education, provincial health and other provincial public services) and does not save.

Finally, the impact on total investment is significant. Total investment in the province decreases by $9.4 \%$, primarily due to the declining savings of all agents in the regional economy. 


\subsection{Comparison to Actual Outcomes in the Free State Post-Crisis}

Comparing the simulated results from the analysis to the observed post crisis trends in the Free State economy can provide valuable insight into the validity of the model and the robustness of the results. The comparison is deliberately up to 2013 since it is not expected that the results of the short run static model project to beyond this period. Firstly, the model results suggest that the recessionary shock of the global financial crisis is likely to impact negatively on local demand and consequently production for goods and services in the Free State province. Falling production levels are likely to result in lower income for firms in the provincial economy, as predicted by the model. This is likely to lead to a lower demand for domestic labour that will result in a downward pressure on wages and/or higher levels of unemployment. Lower levels of wages and employment will impact negatively on the income levels of households. The model finds that such recessionary conditions will apply downward pressure on the general price level in the province, as the economy adjusts to falling demand.

FIGURE 2 assesses the merits of these findings by illustrating the trends in key economic variables post the 2008 crisis. This includes the real growth in the GDPR, the rate of inflation and the growth in total employment in the Free State province.

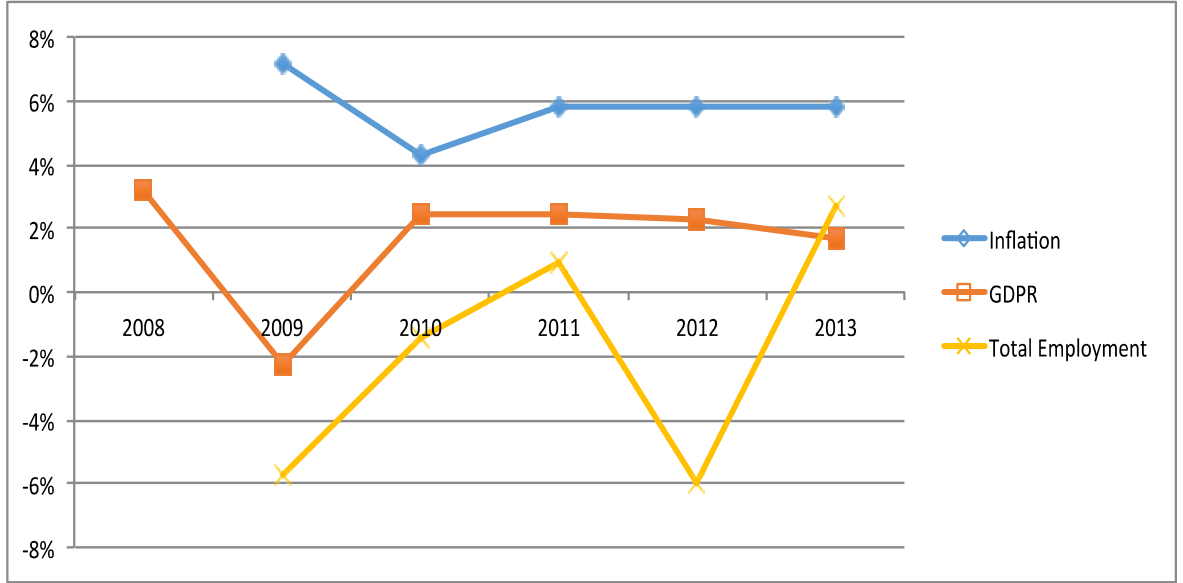

\section{FIGURE 2: Trends in key economic variables in Free State - Post-crisis (\%)}

Source: Statistics South Africa (2013) and IHS Global Insight (2014)

Following the financial crisis, there was a significant decrease in GDPR of $2 \%$ in 2009 . This is likely due to the falling demand and production in the Free State province, a trend that is reflected by the model results. In fact, the average impact on local sales in all sectors was simulated at around $-0.8 \%$, which is close to the observed $-2 \%$ growth in 2009 .

The falling demand and production has a negative impact on prices, which is confirmed by the falling inflation rate in 2010 in FIGURE 2. Generally, the results from the model suggest that the effects of the global financial crisis will negatively impact all agents in the Free State economy. The declining income levels of agents are likely due to a falling demand for local labour and consequently higher unemployment rates. This is confirmed by declining levels of employment in the Free State in FIGURE 2, with increases in employment only occurring in 2013 . The results also suggest that provincial revenues (income) will also be negatively impacted due to lower taxes 
being paid to the national government and to the provincial government. The simulated results represent relatively lower national transfers to provinces but a minimal overall impact on the provincial revenues of $-0.03 \%$ to $-0.13 \%$. FIGURE 3 assesses this finding by illustrating the observed growth in provincial revenue sources post the crisis.

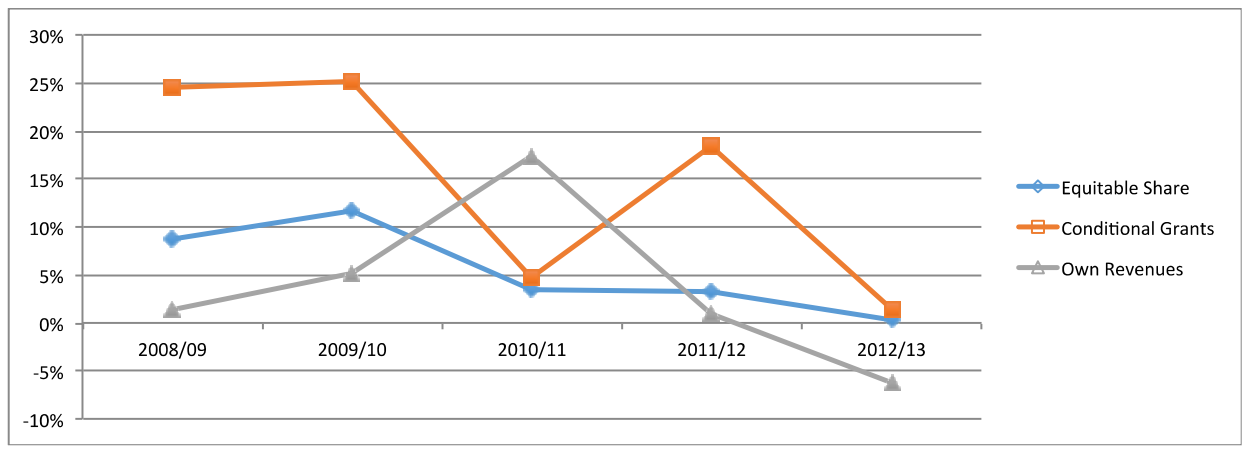

FIGURE 3: Real growth in provincial revenue instruments - Post-crisis (\%)

Source: National Treasury (2014)

Surprisingly, provincial revenues maintained a positive real growth rate following the crisis. The equitable share, which is the largest transfer to provinces, experienced a positive but annually declining growth rate. This suggests that the national fiscus was under pressure during this period and thus could not maintain a steady growth in the equitable share to provinces. On the other hand, real growth in conditional grants, aimed at funding key national policies, remained considerably high but with a significant decline in $2010 / 1$. Although such transfers are smaller than the equitable share, this trend suggests that national government aimed to maintain the funding of its key priority programmes in provinces during the crisis period. Revenues from provincial own tax instruments were surprisingly not strongly decreasing, as one would expect following the crisis. In fact, there was a surge in provincial own revenues in 2010/11, but such revenues experienced declines thereafter. It is possible that there was a longer than expected lag before the impacts of the recession were felt on provincial own revenues.

The relatively positive growth rate in provincial revenues following the crisis allowed the Free State province to maintain steady expenditure levels. FIGURE 4 illustrates the real growth in the different types of provincial expenditure following the crisis. Although current expenditure, which would include the operating costs of providing education and health, maintained a positive trend post the crisis, transfers and subsidies and capital expenditures did experience declining growth rates. This suggests that provinces aimed at maintaining their primary social obligations during the crisis period. All in all, although the model results suggested that provinces are likely to experience a small negative impact on their incomes, it is clear that in reality, national government took extra efforts to support provinces during the crisis and maintain the delivery of key social services. This was likely the result of increasing debt-financed expenditure by national government. 


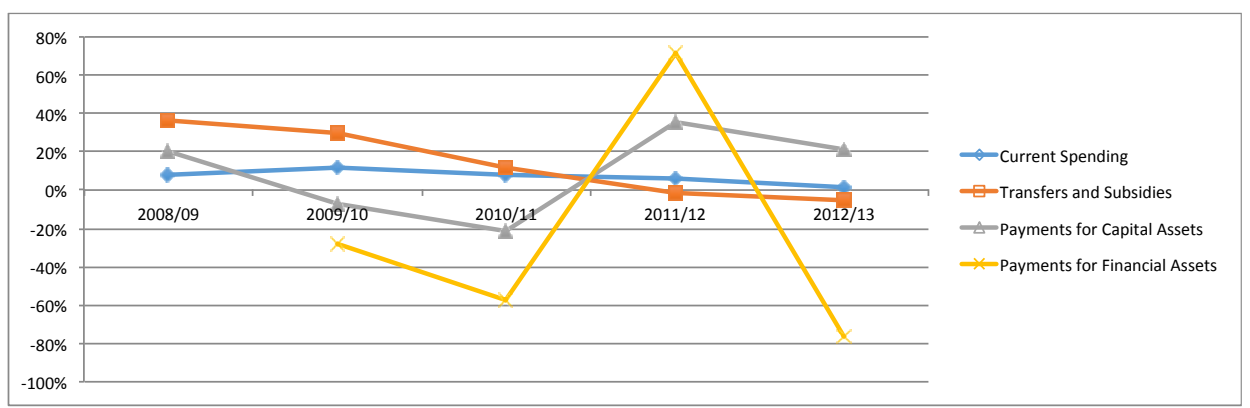

FIGURE 4: Real growth in provincial expenditures per line item - Post-crisis (\%)

Source: National Treasury (2014)

\section{SUMMARY AND CONCLUSIONS}

The legacies of the global financial crisis, which first disrupted global markets in 2007, continue to ripple across the global economic environment. There has been substantial work focusing on the impact of the crisis on national economies. However, less attention has been paid to the subtle, yet significant, process through which crisis-related pressures affected regional economies and sub-national governments.

A regional computable general equilibrium model was developed and used to analyse impacts of the global economic crisis for the regional economy of the Free State province in South Africa. The study provides the first regional assessment of the recession for a South African province using a consistent modelling framework. The paper emphasised the unique socio-demographic status, economic structure and intergovernmental fiscal relations of the Free State, relative to the rest of the country, which justified the need to assess the external shocks emanating from the crisis on a regional level. The impact of the crisis was articulated through a fall in world prices and in global demand and assessed against sectors of the economy grouped by degree of vulnerability to global shocks.

The key results of the model included a general fall in prices in the province, a fall in demand in sectors that are more vulnerable to global conditions, increasing unemployment and falling wages and declining incomes for households, firms and the provincial government. Importantly, although the model results suggested that provinces are likely to experience declining revenues, in reality, national government took extra efforts to support provinces during the crisis and maintain the delivery of key social services. The ex-post comparison of the simulated model results with recently observed provincial social and economic data demonstrates that the model results are consistent with the observed trends. This confirms the validity of the developed model and the robustness of the model results and provides a sense of the status of the provincial economy in the short to medium term, as the impacts of the crisis continue to be felt. Thus, this study represents a significant contribution to the assessment of the global economic crisis on sub-national economies, which offers a basis for further empirical and modelling work in future. 


\section{LIST OF REFERENCES}

Bowo, F. (2009). Impact of financial crisis on local government: Jakarta's experience. Proceedings of the United Cities and Local Government Asia Pacific Meeting and Annual Seminar, 28 April, Kathmandu, Nepal.

Chitiga, M., Decaluwé, B., Mabugu, R, Maisonnave, H., Robichaud, V., Shepherd, D., van der Berg, S. \& von Fintel, D. (2012). Child Poverty in South Africa and the Global Financial and Economic Crisis. In Harper, C., Jones, N., Mendoza, R.U., Stewart, D. \& Strand, E. (eds.) Children in Crisis: Seeking ChildSensitive Policy Responses. Palgrave Macmillan.

Decaluwé, B., Lemelin, A., Maisonnave, H. \& Robichaud V. (2009). PEP-1-1 Standard PEP Model: Single-country, Static Version, Poverty and Economic Policy Network. Université Laval, Québec. Available: http://www.pep-net.org/programs/mpia/pep-standard-cge-models/pep-1-1-singlecountry-static-version. (Accessed 23 September 2014).

Decaluwé, B., Lemelin, A. \& Bahan, D. (2010). Endogenous labour supply with several occupational categories in a bi-regional computable general equilibrium (CGE) model. Regiona/ Studies, 44(10), pp. 1401-1414.

Estrades, C. \& Llambí C. (2013). Lessons from the 2008 financial crisis: policy responses to external shocks in Uruguay. The Developing Economies, 51(3), pp. 233-259.

Free State Provincial Treasury (2006). Provincial Social Accounting Matrix for the Free State Province, Final Report. Bloemfontein: Free State Provincial Government.

Haddad, E.A., Bonet, J., Hewings, G.J.D. \& Perobelli, F.S. (2009). Spatial aspects of trade liberalization in Colombia: A general equilibrium approach. Papers in Regional Science, 88(4), pp. 699-732.

IHS Global Insight (2014). Regional Explorer Database. Pretoria: Global Insight.

National Treasury (2009). Provincial Budgets and Expenditure Review 2005/06 - 2011/12. Pretoria: National Treasury.

National Treasury (2014). Provincial Budget and Expenditure Information. Available:

http://www.treasury.gov.za/documents/provincial\%20budget/default.aspx. (Accessed 10 November 2014).

Partridge, M.D. \& Rickman D.S. (2010). Computable general equilibrium (CGE) modelling for regional economic development analysis. Regiona/Studies, 44(10), pp. 1311-1328.

Statistics South Africa. (2009). Quarterly Gross Domestic Product - First Quarter 2009, puarterly Statistical Release, P0441. Pretoria: Statistics South Africa.

Statistics South Africa. (2012). 2011 Census. Pretoria: Statistics South Africa.

Statistics South Africa. (2013). Quarterly Gross Domestic Product - Forth Quarter 2013, Quarterly Statistical Release, P0441. Pretoria: Statistics South Africa.

Ter-minassian, T. \& Fedelino, A. (2009). Impact of the global crisis on sub-national governments' finances. World Report on Fiscal Federalism: Instituto d'Economia de Barcelona.

The Western Australian Local Government Association. (2009). Impact of the Global Financial Crisis on Regional Australia. Submission to the House of Representatives Standing Committee on Infrastructure, Transport, Regional Development and Local Government. 


\section{Appendix 1: List of activities, commodities in the Social Accounting Matrix}

\begin{tabular}{|c|c|}
\hline Agriculture - Commercial & Other Manufacturing \& Recycling \\
\hline Agriculture - Subsistence & Electricity \\
\hline Gold mining & Water \\
\hline Other mining & Buildings \\
\hline $\begin{array}{l}\text { Meat, Fish, Fruit, Vegetables, Oils and Fat } \\
\text { Products }\end{array}$ & Other construction \\
\hline Dairy products & Trade \\
\hline Grain Mill, Bakery and Animal Feed Products & Accommodation \\
\hline Other food products & Transport services \\
\hline Beverages and tobacco products & Communications \\
\hline $\begin{array}{l}\text { Textiles, Clothing, Leather Products and } \\
\text { Footwear }\end{array}$ & Insurance \\
\hline Wood and Furniture Products & Real estate \\
\hline Paper and Paper Products & Business activities \\
\hline Publishing and Printing & General Government \\
\hline $\begin{array}{l}\text { Chemicals \& Chemical Products (incl Plastic } \\
\text { Products) }\end{array}$ & Health and social work \\
\hline Rubber Products & Activities/services \\
\hline Non-Metallic Mineral Products & National Gov \\
\hline Basic and Structural Metal Products & Provincial Education \\
\hline Other Fabricated Metal Products & Government -Health \\
\hline Machinery \& Equipment & Provincial welfare \\
\hline Electrical Machinery \& Apparatus & Provincial Economic \\
\hline $\begin{array}{l}\text { Communication, Medical and other Electronic } \\
\text { Equipment }\end{array}$ & Provincial Other \\
\hline Manufacturing of Transport Equipment & Localgovernment \\
\hline
\end{tabular}

